\title{
Application of the
} Balanced Scorecard to Realize Strategic Management
of Wildlife Resources

\section{By David R. Rios, Butch Thompson, and Mickey W. Hellickson}

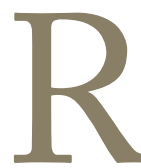

angelands are typically used to produce livestock and to provide habitat for wildlife. In some areas of the United States, it is becoming increasingly profitable for ranchers interested in diversifying their ranching operation to market the opportunity to harvest game species on their ranches through sport hunting. Nonconsumptive enterprises such as wildlife photography and bird watching are also enterprises used by some ranchers to diversify their operation. Commercial hunting enterprises are the most popular because they typically generate more revenue for the rancher. Sport hunting is a multibillion-dollar industry in the United States. Hunting-related expenditures in the United States equal $\$ 21$ billion annually. ${ }^{1} \mathrm{~A}$ great diversity of commercial hunting enterprises exists; day hunts, package hunts, and hunting leases are a few examples.

Commercial hunting enterprises represent one area where strategic management can be utilized to best fit the business enterprise with the environment on a sustainable, long-term basis. However, in the management of many businesses, there is often a disconnect between strategic planning and strategic management. ${ }^{2}$ The Balanced Scorecard is a tool currently available to ranchers to bridge the gap between strategic planning and strategic management of wildlife resources on their ranches (Table 1).

Strategic Planning requires a rancher to explore the following questions: ${ }^{3}$

- Where do we want to be? This question can be addressed by incorporating a shared vision of the future into the strategic plan.

- Where are we now? An evaluation of the strengths, weaknesses, opportunities, and threats of the business, com-

This article has been peer reviewed.
Table 1. Example strategies and corresponding metrics for the wildlife perspective of the Balanced Scorecard for a commercial hunting enterprise

1. Select high-quality customers

- Number of game violations

- Number of harvest mistakes

- Number of rules violations

- Adherence to or deviation from established harvest regulations

2. Develop and maintain long-term relationships with highquality customers

- Follow-up contact post-hunt

- Number of repeat customers

- Number of hunts with repeat customers

3. Develop and maintain an abundance of highly desirable game animals

- Number of trophy-class animals counted during annual preseason game surveys

- Gross Boone and Crockett scores of bucks harvested

4. Add value to the hunting lease through participation in wildlife management programs such as the Managed Lands Deer Permits (MLDP) program in Texas

- Annual browse survey

- Game survey

- Harvest data

monly referred to as SWOT analysis, can help a rancher understand the current position of the business.

- How can we get where we want to be? Gap analysis is a useful technique that can help to answer this question. In 
gap analysis, a comparison between the desired outcome and the expected outcome of the business is made.

- How can we make it work? Strategic options can be generated based on the gap analysis. These strategies should help to bridge the gap between the desired outcome of the business and the expected outcome of the business.

Strategic planning for the management of wildlife resources is commonplace on diversified ranching operations in southern Texas, but are the specific strategies outlined in the strategic plan actually being carried out? Are they truly helping the ranch close the gap between the current reality and the desired vision of the future? The Italian proverb, "It is not enough to aim, you must hit!" truly exemplifies the ambition of strategic management. A rancher must apply a persistent impetus to keep the strategic plan in motion, thus realizing strategic management. This is commonly referred to as a control function. ${ }^{3}$

Strategic management defines the logical methodology to create value for the owners of the business by fitting the business with the environment on a sustainable, long-term basis. ${ }^{3}$ Strategic business management has been applied to businesses from a wide variety of industries. In 1999 Agricultural Economists G. W. Brester and J. B. Penn explored strategic business management to address predicted fundamental changes to the structure of production agriculture. They predicted that the application of strategic business management concepts would be more important for farmers and ranchers during the coming decade than at any other time in the history of agriculture. Farmers and ranchers would have to adopt either a low-cost strategy or a differentiation strategy to survive in the modern age of market globalization, agricultural industrialization, trade liberalization, and ever-increasing human population. ${ }^{4}$ We now see successful farmers and ranchers gravitating toward either product differentiation or very low-cost production. Some producers differentiate their products through value-added programs such as organics and branded beef products, whereas others continue to produce undifferentiated commodity products by keeping production costs at an absolute minimum. Commercial hunting enterprises provide ranchers a third strategic option to address the aforementioned changes in production agriculture: a diversification strategy.

Strategic management involves the actual implementation and control of strategic planning. It requires monitoring and evaluation of the strategies outlined during strategic planning. It answers the question, "Have we succeeded?" The Balanced Scorecard is one approach that can be used as a control function in order to realize strategic management of wildlife resources. ${ }^{3}$

The Balanced Scorecard was developed for use in a general, large business environment, but it can just as easily be applied to diversified ranching operations. The Balanced Scorecard requires the manager to consider the future vision of the business from many perspectives simultaneously, thus providing insight to interactions between and among perspectives and the operation of the entire system. It was originally developed using 1) financial, 2) customer, 3) internal process, and 4) learning and growth perspectives. The original format of the Balanced Scorecard can be built upon by using additional or alternative perspectives as necessary. ${ }^{5}$ The wildlife perspective should be considered when applying strategic planning and management to commercial hunting enterprises. Critical strategies must be identified and implemented to help close the gap between the current reality and the future vision of the ranch when viewed from the wildlife perspective. These strategies must then be monitored and evaluated using a unique set of metrics. The following examples are offered after careful consideration by the authors and in the context of one alternative type of commercial hunting enterprise: hunting leases.

The example vision used for the purpose of this paper is " $T o$ graze cattle at a profit and optimize the profit of the hunting lease enterprise consistent with responsible wildlife and habitat management." We offer the following four example strategies to help close the gap between the current reality and the example vision of the ranch: 1) to select and develop high-quality lessees, 2) establish and continue to develop strong hunting lease agreements, 3) develop and maintain highly desirable hunting leases, and 4) add value to the hunting lease enterprise by participating in programs such as Texas Parks \& Wildlife Department's Managed Lands Deer Permits Program.

\section{Example Strategy and Metrics \#1-Select and Develop High-Quality Lessees}

People management is critical to wildlife management. This is especially true in a hunting lease enterprise where customers inherently wish to maximize the return on their investment. An overzealous group of hunters can decimate game populations and significantly reduce the value of a ranch as a hunting lease. Selective acceptance of hunting lessees is the foundation of this strategy. The rancher must select for lessees with interests that are consistent with, or at least complimentary to, the desired operation of the entire ranch. Lessee fitness can be determined by having prospective lessees complete a lease application, which can be used to conduct a background check to verify the fitness of prospective lessees. Information to collect on the lease application should include legal name, driver's license number, contact information, desired lease arrangement (i.e., corporate, multimember, outfitter, etc.), hunting lease history, and financial references.

Legal name and driver's license number can be used to investigate criminal history. Contact information enables the rancher to contact the prospective lessee in the future. Desired lease arrangement refers to the lessee's desired type of hunting lease. This is important information, because ranchers are typically biased toward or against certain hunting lease arrangements. Every rancher is an individual, and each ranching operation is unique. One rancher might prefer corporate leases, but another landowner might feel that multimember leases better fit the vision of their ranch. 
Hunting lease history includes ranch name, location, acreage, annual lease fee, dates of contract, specific reason lease was terminated, and ranch manager's contact information for all hunting leases previously held. This information can provide great insight to the type of prospective lessee you are dealing with, and allow you to examine the experiences that other ranchers have had with the prospective lessee. Customers in the hunting lease business typically develop accurate and definitive reputations.

Financial references are another great tool. These include bank references, business references, and financial statements. Bank references can provide insight into the prospective lessee's financial status and reputation, business references can provide insight into a prospective lessee's business reputation, and financial statements can confirm the solvency of a prospective corporate lessee.

Once all of this information has been considered and a quality group of lessees has been selected, it is important to continue to develop the lessees in order to work even closer to the vision of the hunting lease enterprise. Lessee development might include such things as an annual preseason meeting to discuss ranch rules, lease boundaries, harvest criteria, and the collection of harvest data in addition to off-season seminars to teach lessees skills such as accurately applying harvest criteria.

Metrics for the strategy of selecting and developing highquality lessees include the collection and consideration of data such as number of game violations, number of harvest mistakes, number of lease or rules violations, and adherence to or deviation from established harvest quotas.

\section{Example Strategy and Metrics \#2-Establish and Continue to Develop Strong Hunting Lease Agreements}

It is critical that high-quality hunting lessees are hunting the ranch under a strong hunting lease agreement. A strong hunting lease agreement allows the rancher to manage hunting lessees, thus managing the wildlife resource. The lease agreement should address lease duration, lease fee, payment/ lack of payment of lease fee, insurance requirements, harvest quotas, selective harvest criteria, lease violations, improvements, road maintenance, and waste disposal. Visit http:// www.naturalresources.umd.edu/Pages/Hunting_Lease.html to view a sample hunting lease agreement and additional information about the content of a hunting lease agreement.

A rancher really doesn't know the strength of his lease agreement until it is challenged or violated. This is when weaknesses in the contract are revealed. In the unfortunate event that a rancher signs a lease agreement with an undesirable lessee, a strong lease agreement will give the rancher the ability to effectively terminate the hunting lease agreement and remove the undesirable lessee from the ranch.

Two questions serve to measure the strength of a lease contract. When evaluating a hunting lease contract, the rancher should ask himself the following questions:
1) Have I been stuck with an undesirable lessee?

2) Has the lease agreement worked against the ranch in any way?

\section{Example Strategy and Metrics \#3- Develop and Maintain Highly Desirable Hunting Leases}

The rancher must develop and maintain highly desirable hunting leases, as the demand for exclusive hunting rights on his ranch will affect the revenue-generating potential of the hunting lease enterprise. Highly desirable hunting leases offer a quality recreational experience. ${ }^{6}$ This requires abundant, high-quality game, and the opportunity to harvest that game. White-tailed deer are the most popular game animal in Texas, and trophy-class animals are highly sought after. A rancher in southern Texas can develop and maintain highly desirable hunting leases by offering the opportunity to harvest trophy-class white-tailed deer. The quality of the trophy is as important a factor in hunting lease fees as the absolute number of animals on a ranch. ${ }^{7}$ Implementation of habitat manipulation, supplemental feeding, harvest quotas and selective harvest criteria are tactics commonly employed by ranchers in southern Texas to execute this strategy.

Game surveys and harvest records are excellent sources of data and can be used as metrics. As a leading indicator, the rancher could monitor the number of trophy-class animals counted during annual preseason game surveys. As a lagging indicator, he might look at gross Boone and Crockett scores of bucks harvested each season.

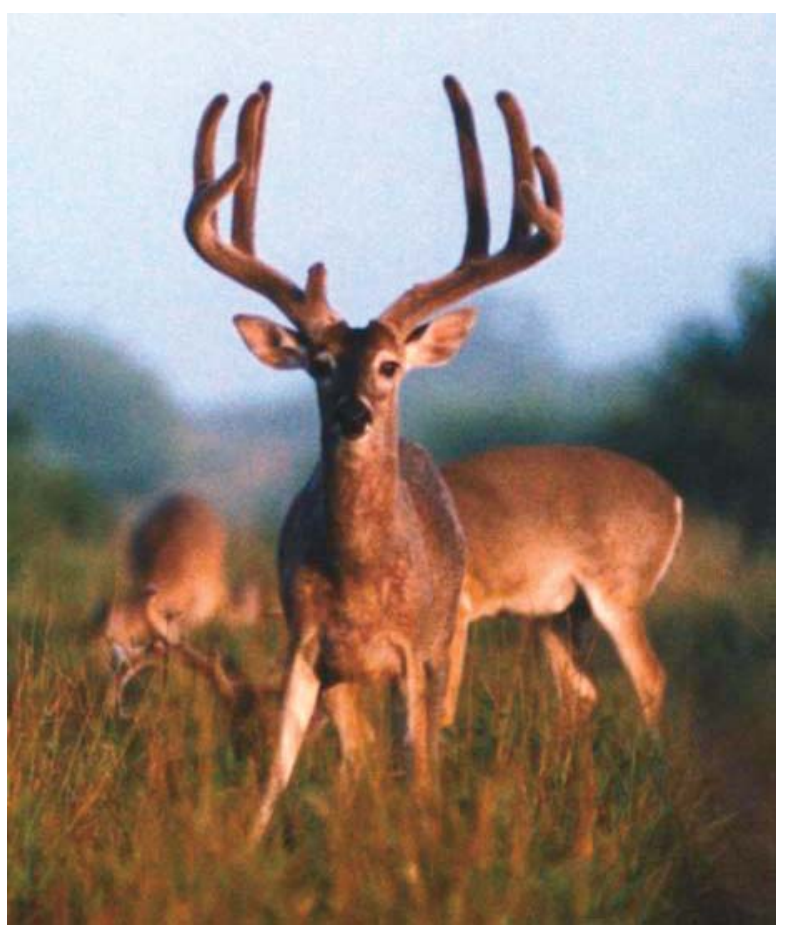

Photo by Mickey W. Hellickson 
Example Strategy and Metrics \#4-Add Value to the Hunting Lease Enterprise by Participating in Programs Such as Texas Parks and Wildlife Department's Managed Lands Deer Permits Program

In order to optimize lease fees, the rancher must make efforts to add value to the hunting lease enterprise. Ninety-eight percent of the land in Texas is privately owned, but the wildlife resource is publicly owned by the people of the state of Texas. Whitetailed deer are economically beneficial to ranchers in Texas, and help to keep large, contiguous tracts of habitat intact by allowing ranchers to generate additional revenue through commercial hunting enterprises. The incentive for conservation is strong when it is profitable to have wildlife on your ranch. ${ }^{1}$

Managing a public resource on private land is a complex endeavor, and Texas Parks and Wildlife Department (TPWD) has been innovative with their approach. One macrostrategy the agency has applied to the management of state-owned wildlife resources on private land is the Managed Lands Deer Permits (MLDP) Program. This incentivebased, habitat-focused program allows ranchers implementing a strategic wildlife management plan to have the state's most flexible seasons combined with increased harvest opportunities. Extended hunting seasons and increased harvest opportunities can add value to a hunting lease while helping to facilitate a rancher's wildlife management plan.

Participation in the MLDP program requires that a written wildlife management plan for the property be approved by a TPWD Biologist. There are three levels of MLDPs (1, 2 , and 3). Harvest flexibility and habitat management requirements increase by level of the MLDP.

The highest level MLDP (Level 3) requires the written wildlife management plan to include deer population data from the current year and 2 preceding years, as well as complete harvest data (age, weight, and antler dimensions) from the 2 preceding years. It must identify a minimum of 4 habitat management practices that are currently being conducted or will be conducted on the ranch. The rancher must accomplish at least 4 of the habitat management practices outlined in the wildlife management plan within 3 years of initial permit issuance. Each year a browse survey is conducted by a TPWD Biologist. The browse survey must indicate that either the habitat is being maintained in an acceptable condition, or the habitat is improving in condition. Otherwise the wildlife management plan will be reevaluated and the MLDP could be suspended.

The rancher benefits from these efforts by having hunting license tag requirements waived and by being allowed a hunting season extended by several months, thus facilitating the harvest goals outlined in the wildlife management plan and adding value to his hunting lease. Visit http://www.tpwd. state.tx.us/business/permits/ for more information about the Managed Lands Deer Permits Program.

By consulting with a state wildlife biologist to write a wildlife management plan, conducting game surveys, collecting harvest data, and conducting habitat improvements on their land, ranchers are able to acquire permits that allow them harvest flexibility and extended seasons for white-tailed deer, thus allowing the rancher to better manage wildlife habitat on his property while adding value to his hunting leases and allowing TPWD to manage a public resource on private land. The wildlife management plan outlines the tactics, and the annual browse survey combined with game surveys and harvest data are the metrics.

\section{Conclusions}

In businesses of all types, there can be a disconnect between strategic planning and strategic management. The Balanced Scorecard is a tool that can be used by ranchers to bridge the gap between strategic planning and strategic management of wildlife resources on their ranches. Table 1 outlines example strategies and metrics that can be applied to the wildlife perspective of a ranch with a commercial hunting enterprise. This basic structure of the Balanced Scorecard can be used to successfully guide and evaluate the wildlife perspective of a ranch in any state. Implementation of the Balanced Scorecard can lead to increased return on investment and more responsible management of wildlife resources by ensuring that management strategies are being implemented and by identifying ineffective management strategies. This allows valuable time and money to be spent on only the most effective strategies.

Authors are Graduate Fellow, King Ranch Institute for Ranch Management, Texas AE'M University—Kingsville, Kingsville, TX 78363-8202, david.r.rios@tamuk.edu (Rios); Resource Manager (Thompson) and Chief Wildlife Biologist (Hellickson), King Ranch, PO Box 1090, Kingsville, TX 78364-1090.

\section{References}

1. Chardonnet, Ph., B. des Clers, J. Fischer, R. Gerhold, F. Jori, ANd F. Lamarque. 2002. The value of wildlife. Revue scientifique et technique - Office International des Epozooties. 21:15-51.

2. Kaplan, S. R., and D. P. Norton. 1992. The balanced scorecard: measures that drive performance. Harvard Business Review 70(1):71-79.

3. Shadbolt, N., and S. Martin. 2005. Farm management in New Zealand. South Melbourne, Victoria 3205, Australia: Oxford University Press. 408 p.

4. Brester, G. W., and J. P. Penn. 1999. Strategic business management principles for the agricultural production sector in a changing global food system. Policy Issues Paper No. 11, November 1999. 11 p.

5. Kaplan, R. S., and D. P. Norton. 1996. The balanced scorecard: Translating strategy into action. Boston, MA: Harvard Business School Press. 322 p.

6. Gramann, J. H. 1986. Market analysis for hunting in Texas. Wildlife Management Handbook. 155 p.

7. BAEn, J. S. 1997. The growing importance and value implications of recreational hunting leases to agricultural investors. Journal of Real Estate Research 14:399-414. 